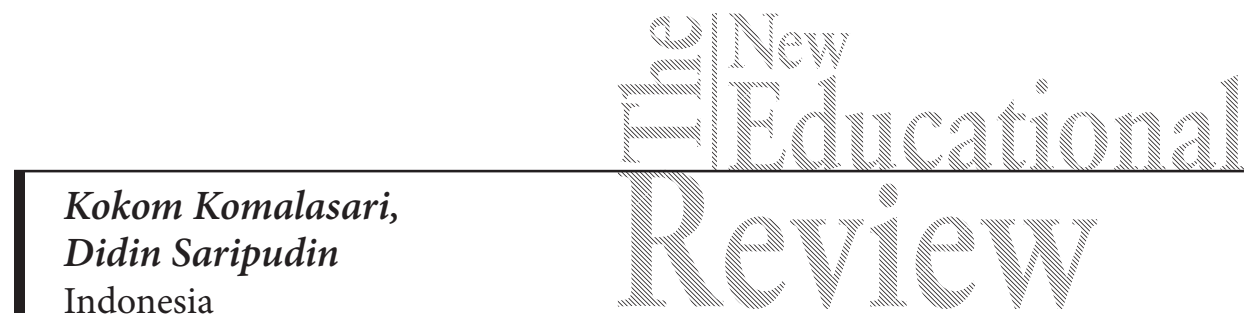

\title{
A Model of Living Values Education-based Civic Education Textbooks in Indonesia
}

DOI: 10.15804/tner.2017.47.1.11

\begin{abstract}
This research aims to develop a model of a civic education textbook on the basis of living values education. This study uses the approach of Research and Development at the stage of product development. Results reveal the following: 1) living values education-based civic education textbooks conceptually incorporate living values and the principles of living values education into the textbook; 2) the textbook chapters include title, introduction, concept roadmap, keywords, presentation of materials, clarification of the values of life, exercises, summary, reflection, authentic assessment, feedback, and follow-up activities; 3) the values of life can be integrated into the textbook through features of civic values, words of wisdom, analysis of life values, reflection, and attitude assessment.
\end{abstract}

Keywords: living values education, textbooks, civic education, character, student, Indonesia

\section{Introduction}

In general, civic education textbooks circulating in the field only primarily teach students about the concepts and principles of science, but put little emphasis on teaching students to act and behave according to the concepts and principles of science in everyday life (Somantri, 2001). How do we reconstruct civic education textbooks so as to help form students' character? First, a civic education text- 
book is to be based on living values, making them more easily internalized and implemented. Second, the textbook needs to involve aspects of knowing the good, desiring the good, loving the good and acting the good. Third, the textbook should be contextual, bridging the material with its real-life application.

All the above characteristics must be integrated into civic education textbooks through a model of living values-based textbooks. A living values-based civic education textbook is a conceptual material associated with students' basic values of life that link their moral knowledge and its application in the lives of students as members of families, communities, and country. Therefore, Research and Development research is necessary to produce a model of a civic education textbook on the basis of living values education assumed to effectively nurture students' character.

\section{Research Problem}

Based on the above background, the problem to be addressed is "what is the concept of a living values education-based civic education textbook?" The detailed formulation of the problem is as follows: 1) What is the conceptual model of a living values education-based civic education textbook model? 2) What is the outline of a living values education-based civic education textbook? and 3) How to integrate living values into a civic education textbook?

\section{Research Focus}

The focus of this research is the development of a living values education-based civic education textbook at junior high school level in Bandung, Indonesia. The research resulted in the conceptual model and outline of a living values education-based civic education textbook, integration of living values education into a civic education textbook, and test results of a limited number of students

\section{Research Methodology}

\section{Research General Background}

The presented study used the Research and Development design. Development basically consists of two main objectives, namely: (1) to develop a product and (2) to measure the effectiveness of the product in achieving the goal (Borg \& Gall, 1989). 


\section{Research Sample}

Research was undertaken in Bandung and West Bandung Regency, West Java, Indonesia. Subjects were students and teachers at junior high schools that serve as pilot sites for the implementation of the Curriculum of 2013, i.e., SMPN 2 Bandung, SMPN 5 Bandung, and SMPN 1 Lembang.

\section{Instrument and Procedures}

Data collection instruments used in this study include (1) an observation/ participation sheet, (2) documentation study, (3) interviews, and (4) questionnaire. The results of the research on the development stage of the product/model include the following steps: research and information collection, planning, development of a preliminary form of the product, preliminary field testing, and main product revision.

\section{Data Analysis}

Qualitative data analysis was carried out through the following steps: (1) data reduction by summarizing reports, noting the key points that are relevant to the research focus; (2) systematic data organization based on specific categories and classifications; (3) data display in the form of tables or graphics so that the relationship among the data is clear and coherent; (4) cross-site analysis by in-depth comparing and analyzing the data; and (5) presentation of the findings, drawing conclusions in the form of general trends and the implications of implementation, and recommendations for development (Fraenkel and Wallen, 2006). Quantitative data analysis was performed through quantitative data analysis using a quantitative description (Creswell, 2012).

\section{Research Results}

\section{The Conceptual Model of Living Values Education-based Civic Education Textbooks}

Conceptually, LVE-based civic education textbooks incorporate living values and the principles of living values education into the textbook by taking into account the principles of scientific learning and contextual learning, developing core competences and basic competences in line with the Curriculum of 2013, the principles of the preparation of textbook material, language and legibility, and appearance (graphics). Based on the above, the principles of writing LVE-based civic education textbooks are as follows: 
1. Develop living values

Living values that will be integrated into the civic textbooks are clearly described. The values of life are developed with reference to Saripudin and Komalasari (2015) and Tillman (2004) as follows: peace, respect, love, tolerance, honesty, humility, cooperation, happiness, responsibilities, simplicity, freedom, and unity.

2. Develop principles of living values education (Tillman, 2004), which include: gathering points of reflection, imagining, training relaxation and focus, expressing artistic creations, developing social skills, developing a cognitive awareness of justice, developing social cohesion, and assembling cultural values.

3. Apply the learning principles of writing textbooks, which include readiness, motivation, use of attention getters, students' active participation through a scientific and contextual approach, repetition, feedback, a cognitive vision of social interaction, authentic assessment, reflection, and life skills (Komalasari, 2012).

4. Develop core competences and basic competences in the curriculum, namely: a) substantial knowledge students should acquire and understand; b) skills, i.e., practical ability developed from knowledge, which can be used to cope with the problems of life; and c) the attitude, i.e., the character every student should have to support effective participation in life.

5. Observe the principles of the preparation of textbook material, which should be: a) accurate; b) relevant; c) self-sufficient; d) consistent; e) actual; and f) the structure of science.

6. Language and legibility should meet the following criteria: 1) sentences used should be in accordance with the grammar of formal Indonesian; 2) the structure of sentences should indicate logical and systematic thinking; 3 ) the structure of sentences should be in accordance with students' level of proficiency; and 4) sentences should be communicative.

7. Layout principles: 1) formatting and 2) illustration of figures and tables should support or clarify the concepts presented.

\section{Outline of Chapters of Living Values Education-based} Civic Education Textbooks

Based on the conceptual model of the LVE-based civic textbook delineated above, the contents of the book are presented as follows:

1. Title is meaningful 
2. Introduction begins with images, stories, poems, cases, etc., followed by apperception and reflection of living values to be discussed.

3. Road map of concepts and keywords serves as an overview of the material that will be presented and the values of life that will be developed in the chapter.

4. The materials presented in the book include facts, concepts, principles, procedures, and values of life.

5. Assignments/exercises; students are asked to perform a series of practical tasks of citizenship in improving citizenship competences.

6. Summary contains conclusions of the material to learn and the values of life to develop.

7. Reflection contains reflections on life values practiced in everyday life through a Value Clarification Technique list. This reflection can be utilized as an instrument to assess students' attitudes and behavior.

8. Authentic assessment contains a series of student assessment instruments.

9. Providing feedback section presents the answer key and assessment form accompanied by assessment rubric.

10. Follow-up activities (transfer, enrichment, remedial) provide enrichment activities for those who have reached the expected competences and remedial activities for those who have not.

\section{Integration of Living Values Education into Civic Education Textbooks}

Integration of the values of life into a civic textbook is realized, among other things, through features of civic values, words of wisdom, exercises on the content of the story that is packed with values, reflection and self-assessment. The following exemplifies the integration of the values of life into a civic textbook for Grade 7, Chapter 3 on "The Commitment to Maintaining the Constitution of the Republic of Indonesia”.

\section{Features of civic values}

On the sideline of material descriptions, the values of life are displayed in a special feature entitled "civic values". In this section, there is a special box that presents the values of life in accordance with the context of the material, such as patriotism, solidarity, tolerance, compassion, unconditional attitude, responsibility, and strong spirit. The values presented are to be applied by the students in their everyday life. Examples are presented below. 
Based on the meaning of the Preamble of the Constitution of the Republic of Indonesia Year 1945, as described above, the Constitution of the Republic of Indonesia Year 1945 is a detailed elaboration of the proclamation. Proclamation of independence brings forth to the people of Indonesia the independence of Indonesia that is united, sovereign, just and prosperous. The statement is stipulated in the second paragraph of the Preamble of the Constitution of the Republic of Indonesia Year 1945.

\section{Civic Value}

In the process of formulation of the 1945 Constitution, the founders of our country established the following principles:

1. Pro patria and primus Patrialis, i.e., love the country and prioritize the interests of the country.

2. Solidarity

3. Tolerance towards different religions, ethnicities, groups and nations

4. Selfless attitude and responsibility 5. Strong spirit and great soul

2. Words of wisdom associated with the values of life Material presentation is also equipped with wise words of local, national, regional, and international figures that can inspire students. Wise words are adapted to the context of the material covered in the book. For instance, in discussing the "Formulation Process of the Constitution of the Republic of Indonesia", the given wise words are related to the value of patriotism from an Indonesian cultural figure as follows:

\section{Value of Life:}

"... because loving your country is to feel part of the country, feel connected to a community, feel that the self, identity and destiny are interwoven with something called Indonesia, or Japan, or the United States. Loving a country is to feel, perhaps to realize that there is no other country, no other nation, but your own, which could move your heart in such a way to live, work and even to die (Goenawan, 1995)

\section{Exercises on the contents of a story rich with the values of life}

The values of life are incorporated into assignment/exercises. In this section, the values of life are packaged in the form of stories, poems, songs, and pictures. Students analyze the content, explore and clarify the values of life in it, as well as elaborate efforts to make it happen in everyday life (Saripudin and Komalasari, 2016b). Examples are presented below. 
Read the story below!

\section{Farmer and His Children}

A very wealthy farmer, who feels that he is not going to live much longer, calls his children to his bedside.

"My children," he says, "Listen to what I'll tell you. For whatever reason, do not ever sell the land that has belonged to our family for generations because there is a hidden treasure. I don't know where, but the treasure is there. Look for the treasure as best as you can by digging and do not miss an inch of land."

The farmer then dies, and not long after the funeral, the children begin to work as hard as possible to dig every inch of their land with a shovel. They do so over and over.

No hidden gold is found, but at harvest time, they have a lot more money than their neighbors due to lots of crops. In the end they realize that the treasure is actually abundant harvest and their hard work.

After you have read the story, answer the questions below.

1) What conclusions can you draw from the story?

2) What are the good things you can extract from the story?

3) How can it be linked to the contents of the preamble of the Constitution of 1945 ?

4) What does it take to materialize the four points of the Constitution?

4. Learners are asked to reflect on their understanding of the material and the application of behavioral attitudes in everyday life

At the end of the chapter, students carry out reflection to evaluate their understanding of the material and its application in everyday life, which indirectly teaches students about the value of honesty, responsibility, and respect.

5. Self-assessment

Evaluation not only measures students' understanding of the material, but importantly also assesses the students in the application of the values of life by filling in the Self-Assessment Checklist.

\section{Test Results of a Limited Number of Students}

To find out the aspects of the understanding of the content and development of character, after using the textbook, a test was administered to examine the learners' understanding and attitudes. Aspects of understanding and development of character are presented in Table 1. 
Table 1. Understanding of material and development of character

\begin{tabular}{|c|c|c|c|c|c|c|}
\hline \multirow[b]{2}{*}{ Nr. } & \multirow[b]{2}{*}{ Components assessed } & \multirow[b]{2}{*}{$\begin{array}{l}\text { Aspects as- } \\
\text { sessed }\end{array}$} & \multicolumn{4}{|c|}{ Assessment Results $(\mathrm{N}=207)$} \\
\hline & & & $\begin{array}{c}\text { Very } \\
\text { Good } \\
(\%)\end{array}$ & $\begin{array}{c}\text { Good } \\
(\%)\end{array}$ & $\begin{array}{l}\text { Enough } \\
(\%)\end{array}$ & $\begin{array}{l}\text { Less } \\
(\%)\end{array}$ \\
\hline \multirow[t]{5}{*}{ A. } & \multirow{5}{*}{$\begin{array}{l}\text { Understanding of the } \\
\text { Material in the } 2013 \\
\text { Curriculum }\end{array}$} & Fact & 60 & 27 & 7 & 6 \\
\hline & & Concept & 53 & 26 & 12 & 9 \\
\hline & & Principle & 49 & 23 & 15 & 13 \\
\hline & & Procedure & 52 & 23 & 10 & 15 \\
\hline & & Living values & 70 & 14 & 11 & 5 \\
\hline \multicolumn{3}{|c|}{ Average Score of Component A } & 56.80 & 22.60 & 11.00 & 9.60 \\
\hline \multirow[t]{12}{*}{ B. } & \multirow{12}{*}{$\begin{array}{l}\text { The development of } \\
\text { living values }\end{array}$} & Peace & 55 & 15 & 20 & 10 \\
\hline & & Respect & 64 & 18 & 14 & 2 \\
\hline & & Love & 65 & 19 & 12 & 6 \\
\hline & & Tolerance & 80 & 11 & 7 & 2 \\
\hline & & Honesty & 30 & 30 & 20 & 20 \\
\hline & & Humility & 53 & 20 & 18 & 9 \\
\hline & & Cooperation & 75 & 12 & 10 & 3 \\
\hline & & Happiness & 54 & 24 & 20 & 2 \\
\hline & & Responsibilities & 50 & 20 & 20 & 10 \\
\hline & & Simplicity & 60 & 19 & 15 & 6 \\
\hline & & Freedom & 48 & 30 & 20 & 2 \\
\hline & & Unity & 78 & 13 & 8 & 1 \\
\hline \multicolumn{3}{|c|}{ Average Score of Component B } & 59.33 & 19.25 & 15.33 & 6.09 \\
\hline
\end{tabular}

The above table shows that the learners have good skills in understanding the material and the living values. In the aspect of understanding of the material according to the 2013 curriculum, the learners have the best ability in understanding the facts and living values. In the aspect of the development of living values, the most dominant is tolerance, unity, cooperation, love, and respect.

\section{Discussion}

The results of this study are explainable in the following pointers: First, LVEbased textbooks serve as a primary source of knowledge for students, through which the students can understand the material, develop the values of life and 
apply them. This is in agreement with expert opinions that a textbook is an instructional medium that plays a prominent role in the classroom; a means of delivering curriculum material; and a central part in an education system (Patrick, 1988; Locked and Verspoor, 1990; Altbach, et al., 1991; Buckingham, 1960; Saripudin and Komalasari, 2015). More specifically, Chambliss and Calfee (1998) explain that textbooks are tools by which students understand and learn from what they read. Textbooks are also the tools to understand the world. Textbooks have crucial roles to play (Greene and Petty, 1971). Textbooks have big power to change the brain, especially that of the student. They also affect students' knowledge and values. Textbook writing should, therefore, be thoroughly organized.

Second, LVE-based textbooks not only present the subject matter in the curriculum, but more importantly assist students in learning the material and develop the character and values of life, as well as a strong desire to apply them in everyday life. Therefore, textbooks should contain the subject matter suited to the prevailing curriculum, practical values of life according to students' needs, and learning experiences for students to discover materials and living values on their own (Komalasari et al., 2014; Komalasari and Sapriya, 2016). This is in accordance with the view of Hanna and Lee (1962) that a book should contain materials from disciplines, the environment, and students' responses to both. The contents and values developed in a textbook should meet students' needs in a balanced way and be organized in a functional, structural, humanistic, and civic approach. The contents must be scientific, logical, systematic, developmentally appropriate, using a spiral approach, and include informative and attractive illustrations (Sjamsuddin, 2004). A good book not only contains the correct concept in science and has an attractive layout but most importantly it teaches students. Therefore, textbook writers should pay attention to the learning strategy components and design of subject matter (Gafur, 1986; Komalasari, 2010).

Third, LVE-based textbooks empower students to live independently and to understand textual and contextual materials. The roles of such textbooks in empowering students include: (1) the book should be a source of information while teachers as agents and sellers of such information; (2) the book should stimulate students' interests to acquire information; (3) the book should serve as the manager of students' learning activities, presenting information at the gradual levels of difficulty, including practice questions and solutions; (4) the book should satisfy the requirements of the curriculum and cover the implementation of curricular contents; (5) the book should be utilized as a discourse to train reasoning skills and the formation of students' attitudes in the face of the relatively fast changing world in the $21^{\text {st }}$ century; (6) the book should contain essential and 
strategic information and serve as a useful tool in problem solving; and (7) the book should present communicative and interesting information (Martono, 2005; Saripudin and Komalasari, 2016a).

Fourth, the presence of LVE-based text books does not exclude the role of the teacher. It is undeniable that the teacher plays a central role in facilitating students to use textbooks as a learning resource so that the students can optimally utilize the textbooks to develop a comprehensive understanding, attitudes, and behavior. The teacher is a facilitator, who has authority and responsibility at individual and classical level in the process of students' acquiring knowledge through a variety of activities and experiences in the learning process considering varying levels of students' proficiency and characters. In addition, the formation of students' attitudes and beliefs can be influenced by the teacher's role and professionalism (Komalasari and Saripudin, 2015).

\section{Conclusions}

A LVE-based civic education textbook model conceptually incorporates living values and principles of living values education into the textbook by observing the principles of contextual learning, developing core competences and basic competences in the existing curriculum, learning principles of writing textbooks, language and legibility, and layout. The contents of the book encompass: title, chapters/discussions, introduction, road map of concepts and keywords, presentation of materials and clarification of living values, assignments/exercises, summary, reflection, authentic assessment, giving feedback and follow-up activities. The values of life can be integrated into the textbook through civic value features, words of wisdom related to the values of life, review of the story that contains the values of life, reflection, and attitude assessment. The book is expected to be used as a learning resource in civic education in fostering students' character. This LVE-based civic textbook is an innovation in the provision of quality learning resources, particularly in developing students' character. The book is expected to be used by students and teachers as a learning resource in civic education at junior high school in Indonesia.

\section{Acknowledgements}

The research is a grant from the Ministry of Research, Technology, and Higher Education of Indonesia through the Competence Research Program. The author would like to express sincere appreciation for the support provided. 


\section{References}

Altbach, P.G., Kelly, G.P., and Petrie, H.G. (1991). Textbooks in American Society: Politics, Policy, and Pedagogy. Buffalo: SUNY Press.

Borg, W. R., and Gall, M.D. (1989). Educational Research: An Introduction (5 ${ }^{\text {th }}$ ed). New York: Longman.

Buckingham, B.R. (1960). “Textbooks”, in Encyclopedia of Educational Research, Third Edition, (ed.) Chester W. Harris, (ass.) Marrie R. Liba. New York: The MacMillan Company.

Chambliss, M.J., and Calfee, R.C. (1998), Textbooks for Learning: Nurturing Children's Minds, Massachusetts: Blackwell Publishers.

Creswell, J.W. (2012). Educational Research : Planning, Conducting, And Evaluating Quantitative And Qualitative Research. Boston : Pearson Education, Inc.

Fraenkel, J.R., \& Wallen, N.E. (2006). How to Design and Evaluate in Research. New York: The McGraw-Hill Companies, Inc.

Gafur, A. (1986). Desain Instructional: Suatu Langkah Sistematis Penyusunan Pola Dasar Kegiatan Belajar Mengajar. [Instructional Design: Systematic Steps in Preparation of Basic Pattern of Teaching and Learning Activities]. Solo: Tiga Serangkai.

Greene, H., and Petty, W.T. (1971). Developing Language Skills in the Elementary Schools. Boston: Allyn and Bacon, Inc.

Goenawan, M. (1995). Catatan Pinggir 4. [Edge Note 4]. Jakarta: Pustaka Utama Grafiti.

Hanna, P. and Lee, J. (1962). Content in the Social Studies. In Michaelis, J.U. (ed). (1962). Social Studies in Elemenary Schools, 32 nd Yearbook. Washington D.C.: NCSS.

Komalasari, K. (2010). Pembelajaran Kontekstual: Konsep dan Aplikasi. [Contextual Teaching and Learning: Concept and Application]. Bandung: Refika Aditama.

Komalasari, K. (2012). The Living Values-Based Contextual Learning to Develop the Students' Character. Journal of Social Sciences, 8, 246-251. doi: 10.3844/jssp.2012.246.251.

Komalasari, K., Saripudin, D., and Masyitoh, I.S. (2014). Living Values Education Model in Learning and Extracurricular Activities to Construct the Students' Character. Journal of Education and Practice, 5, 166-174.

Komalasari, K., and Saripudin, D. (2015). Integration of Anti-Corruption Education in School's Activities. American Journal of Applied Sciences, 12, 445-451. doi: 10.3844/ ajassp.2015. 445.451

Komalasari, K., and Sapriya. (2016). Living Values Education in Teaching Materials to Develop Students' Civic Disposition. The New Educational Review, 44, 107-124. doi: 10.15804/tner. 2016.44.2.09

Locked, M., and Verspoor, A. (1990). Improving Primary Education in Developing Countries: A Review of Policy Options. Washington DC: World Bank.

Martono, K. (2005). Peranan Buku dalam Proses Belajar Mengajar. [The Role of a Book in Teaching and Learning]. Retrieved 1/12/2014 from www.ganeca.blogspirit.com

Patrick, J.J. (1988). High School Government Textbooks. Eric Digest, Ed 301532, retrieved 5/12/2015 from https://eric.ed.gov/?id=ED301532.

Saripudin, D., and Komalasari, K. (2015). Living Values Education in School's Habituation 
Program and Its Effect on Student's Character Development. The New Educational Review, 39, 51-62.

Saripudin, D. and Komalasari, K. (2016a). The Development of Multiculturalism Values in Indonesian History Textbook. American Journal of Applied Sciences, 13, 827-835. DOI:10.3844/ajassp.2016.827.835.

Saripudin, D. and Komalasari, K. (2016b). Culture-based Contextual Social Studies Learning for Development of Social and Cultural Values of Junior High School Students. The Social Sciences, 11, 5726-5731. doi: 10.3923/sscience.2016.5726.5731.

Sjamsuddin, H. (2004). Penulisan Buku Teks Sejarah: Kriteria dan Permasalahannya. [Writing of a History Textbook: Criteria And the Problem], Historia, 1, 1-12.

Somantri, N. (2001). Menggagas Pembaharuan Pendidikan IPS [Promoting Social Studies Reform]. Bandung: Remadja Rosdakarya.

Tillman, D. (2004). Living Values: Activities for Children Ages 8-14. Jakarta: PT Gramedia Widiasarana Indonesia. 